\title{
The Effect of Bacillosporin A, from Terolomyces bacillosporus, on Mitochondrial Respiration
}

\author{
H. ShIOJIRI*1, T. NAKamaRU*1, K. Hisada*1, K. KaWAi"1 \\ Y. NOZAWA*1, E. OKUYAMA ${ }^{* 2}$, and M. YAMAZAKI*2 \\ 塩尻 博之*1, 中丸 輝彦*1, 久田 和夫*1, 河合 清*1 \\ 野沢 義則*1, 奥山 恵美 ${ }^{* 2}$, 山崎 幹夫*2 \\ ミトコンドリア呼吸系への bacillosporin A の影響
}

\begin{abstract}
The effect of bacillosporin A, from Taralomyces bacillosporus, on oxidative phosphorylation in mitochondria was examined. Bacillosporin A was found to uncouple the oxidative phosphorylation, causing $50 \%$ uncoupling at 5-7 $\mu \mathrm{M}$, and to depress the state 3 respiration, causing $50 \%$ inhibition at $20 \mu \mathrm{M}$. Bacillosporin A inhibited the oxygen uptake of electron transport particles (ETP) oxidizing succinate, causing $50 \%$ inhibition at about $70 \mu \mathrm{M}$. But none of succinic dehydrogenase, succinic-cytochrome $c$ reductase, and cytochrome $c$ oxidase were speciffcally and strongly inhibited by this compound.
\end{abstract}

\section{Introduction}

Bacillosporin A (Fig. 1), which is chemically related to duclauxin, xenoclauxin, and desacetylduclauxin from Penicillium duclauxii $(1,2)$, has been isolated from Talaromyces bacillosporus (3), but its toxicity and biological activity including the inhibitory effect on mitochondrial respiration are not known yet. Duclauxin, xenoclauxin, and desacetylduclauxin have been demonstrated to exhibit cytotoxicity to L1210 murine leukemia cells and to strongly disturb mitochondrial respiration $(4,5)$. It is, therefore, not unreasonable to expect that bacillosporin $\mathrm{A}$ also should exert cytotoxicity to

*1 Department of Biochemistry, Gifu University School of Medicine (Tsukasamachi 40, Gifu 500)

岐阜大学医学部生化学教室（干500 岐阜市司町 40)

*2 Research Institute for Chemobiodynamics, Chiba University (Inohana 1-8-1, Chiba 280) 千葉大学生物活性研究所（干280 千葉市亥鼻18-1) culture cells and inhibitory effect to mitochondrial respiration. In the present study, the effects of bacillosporin $\mathrm{A}$ on the oxidative phosphorylation and respiratory chain were examined using isolated rat liver mitochondria and ETP which are reverted membrane vesicles of mitochondrial inner membranes. Bacillosporin A was found to strongly disturb mitochondrial respiration by a similar manner to those of duclauxin and xenoclauxin, causing the uncoupling of oxidative phosphorylation and depression of state 3 respiration in mitochondria.

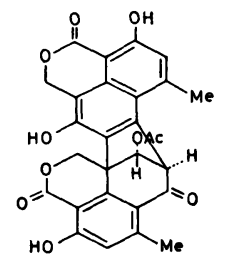

BACILLOSPORIN A

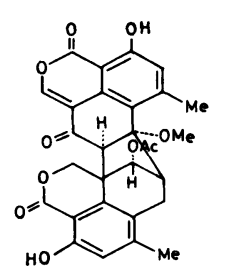

DUCLAUXIN
Fig. 1. Structures of bacillosporin A and duclauxin. 


\section{Materials and Methods}

Reagents Bacillosporin A was isolated by Yamazaki and Okuyama (3) from Talaromyces bacillosporus and was dissolved in N, N-dimethylformamide. ADP, Tris, and cytochrome $c$ (type III from horse heart) were products of Sigma Chemicals Co. Bovine serum albumin (BSA, fraction V) was purchased from Armour Pharmaceutical Co. Other reagents from Nakarai Chemical Co. were of the analytical grade.

Procedures Preparation of rat liver mitochondria and measurement of mitochondrial respiration were performed by the same method as previous report (5), using Galvani-type oxygen electrode" (Sensanics Japan Co.). Electron transport particles (ETP) were prepared from rat liver mitochondria according to the procedure of Ruzicka and Crane (6). Reaction mixture for the measurement of respiration by mitochondria and ETP was composed of 787.5 $\mu \mathrm{mol}$ sucrose, $35 \mu \mathrm{mol} \mathrm{KCl}, 17.5 \mu \mathrm{mol} \mathrm{MgCl}_{2}, 17.5$ $\mu \mathrm{mol}$ phosphate, $1.75 \mu \mathrm{mol}$ EDTA, and $70 \mu \mathrm{mol}$ Tris-Cl in a final volume of $3.5 \mathrm{ml}$. Reaction was carried out at $30^{\circ} \mathrm{C}$. Succinic-cytochrome $c$ reductase activity was measured monitoring the absorbance increase at $550 \mathrm{~nm}$ caused by reduction of cytochrome $c(7)$. Reaction mixture contained 562.5 $\mu \mathrm{mol}$ sucrose, $25 \mu \mathrm{mol} \mathrm{KCl}, 12.5 \mu \mathrm{mol} \mathrm{MgCl}_{2}, 115$ $\mu \mathrm{mol}$ cytochrome $c$, and $50 \mu \mathrm{mol}$ Tris-Cl in a final volume of $2.5 \mathrm{ml} \mathrm{(} \mathrm{pH} \mathrm{7.4)}$. Spectrophotometric analysis was performed using Hitachi 320 S recording spectrophotometer. Protein concentration was determined by the method of Lowry et al. (8), using BSA as a standard protein.

\section{Results and Discussion}

The effect of bacillosporin $\mathrm{A}$ on oxidative phosphorylation was examined, using isolated rat liver mitochondria and the results were summarized in Fig. 2. Freshly prepared mitochondria exhibited a tightly coupled respiration, giving high values of $\mathrm{RC}$ index and $\mathrm{P} / 0$ ratio. Bacillosporin $\mathrm{A}$ was found to markedly decrease the $\mathrm{RC}$ index and $\mathrm{P} / \mathrm{O}$ ratio in a dose dependent manner, indicating an uncoupl-

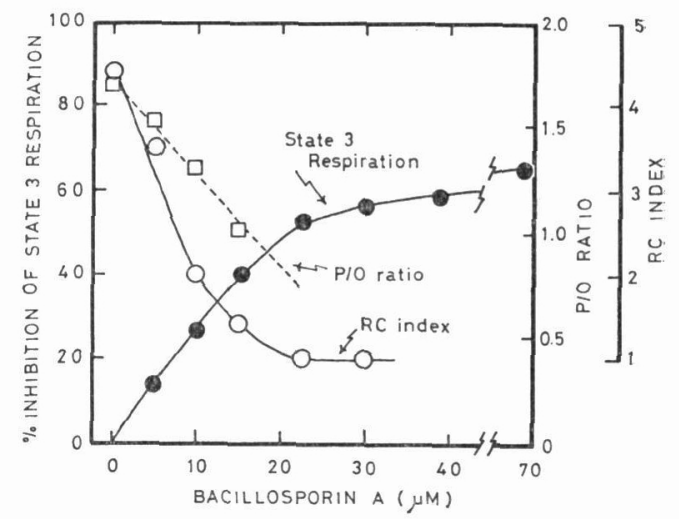

Fig. 2. Effect of bacillosporin A on oxidative phosphorylation in mitochondria.

Reaction was initiated by adding mitochondria ( $3.15 \mathrm{mg}$ protein) and $15 \mu \mathrm{mol}$ succinate. State 3 respiration was obtained by adding $450 \mathrm{nmol}$ ADP. Other detailed conditions were mentioned in MATERIALS AND METHODS.

ing effect of this compound to the oxidative phosphorylation in mitochondria. Fifty percent inhibitions in $\mathrm{RC}$ index and $\mathrm{P} / \mathrm{O}$ ratio were observed at 7 and $15 \mu \mathrm{M}$, respectively. State 3 respiration was also strongly depressed by this compound, giving $50 \%$ inhibition at about $20 \mu \mathrm{M}$, as observed for duclauxin $(4,5)$ and xenoclauxin (5). Mitochondrial respiration oxidizing L-glutamate, a NAD-linked substrate, was also depressed by this compound (data not shown).

The effect of bacillosporin $A$ on the respiration of ETP, which are reverted membrane vesicles of mitochondrial inner membsanes, was examined to gain insight into the mechanism for the inhibition of the state 3 respiration by bacillosporin A (Fig. 3). Bacillosporin A was found to inhibit succinoxidase activity (oxygen consumption of ETP oxidizing succinate), though higher concentrations of bacillosporin $\mathrm{A}$ were needed to cause $50 \%$ inhibition (about $70 \mu \mathrm{M}$ ) than those for the inhibition of intact mitochondria, which implies that bacillosporin A interferes with both respiratory chain and ion translocation across mitochondrial inner membranes. $\mathrm{NADH}$ oxidation was also depressed by this compound, again at relatively high concentrations (data 


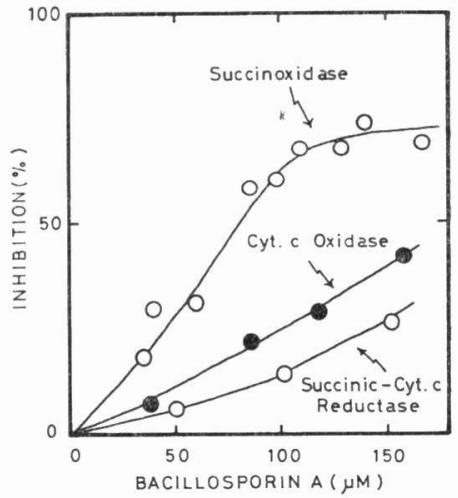

Fig. 3. Effect of bacillosprin A on respiratory chain in ETP. Succinoxidase activity: Reaction was initiated by adding ETP (1.2 $\mathrm{mg}$ protein) and $15 \mu \mathrm{mol}$ succinate. Other conditions were same as in Fig. 2.

Cytochrome $c$ oxidase activity: Reaction mixture contained tetramethyl-p-phenylenediamine (TMPD) in addition to the same basal components as in Fig. 2. Reaction was initiated by adding ETP (1.2 mg protein) and $32 \mu \mathrm{mol}$ ascorbate. Other conditions were same as in Fig. 2.

Succinic-cytochrome $c$ reductase activity: Reaction mixture contained $115 \mu \mathrm{mol}$ cytochrome $c$ in addition to the basal component. Reaction was initiated by adding ETP ( $1.2 \mathrm{mg}$ protein) and $15 \mu \mathrm{mol}$ succinate. Other conditions were described in MATERIALS AND METHODS.

not shown). The effect of bacillosporin $\mathrm{A}$ on cytochrome $c$ oxidase (complex IV) activity of ETP oxidizing ascorbate was examined, using oxygen electrode. The inhibition of bacillosporin $\mathrm{A}$ to cytochrome $c$ oxidase was seen to be significantly weaker than that to succinoxidase. The effect of bacillosporin $\mathrm{A}$ on succinic-cytochrome $c$ reductare (complexes II and III) was spectroscopically mea- sured by monitoring the absorbanse at $550 \mathrm{~nm}$ which was caused by the reduction of externally added cytochrome $c$. The reduction rate of cytochrome $c$ was decreased by bacillosporin $\mathrm{A}$, indicating an inhibition of succinic-cytochrome $c$ reductase. But the inhibition rate was smaller than that in cytochrome $c$ oxidase. These results indicate that none of complexes II, III, and IV in the respiratory chain are specifically inhibited by bacillosporin A. It was thus speculated that bacillosporin $\mathrm{A}$ was able to inhibit the state 3 respiration by non-specifically depressing each enzyme involving in the respiratory chain by a fashion of multi-site inhibition and in addition, by depressing membrane translocation of anion(s) across inner membranes. Further detailed study was not performed due to the limited amount of sample. The potent disturbance of bacillosporin A on ATP synthesis system in mitochondria may imply the cytotoxicity of this compound.

\section{References}

1) Shibata, S., Ogihara, Y., Tokutake, N., Tanaka, O.: Tetrahedron Lett. 128 (1965).

2) Ogihara, Y., Tanaka, O., Shibata, S.: Tetrahedron Lett. 286 (1966).

3) Yamazaki, M., Okuyama, E.: Chem. Pharm. Bull. 28, 3649 (1980).

4) Shiojiri, H., Kawai, K., Kato, T., Ogihara, Y., Nozawa, Y.: Proc. Japan. Assoc. Mycotoxicol. 18, 38 (1983).

5) Kawai, K., Shiojiri, H., Nakamaru, T., Sugie, S., Mori, H., Kato, T., Ogihara, Y., and Nozawa, Y.: Cell Biol. Toxicol. in press (1985).

6) Ruzicka, H. J., Crane, F.: Biochim. Biophys. Acta 233, 71 (1970).

7) King, T.E.: Methods in Enzymol. (Academic Press) 10, 216 (1967).

8) Lowry, O. H., Rosenbrough, N. J., Farr, A.L., Randall, R. J.: J. Biol. Chem. 193, 265 (1951). 